\title{
Job Burnout and Organizational Cynicism Among Employees in Nigerian Banks
}

\author{
Dr. Omoankhanlen Joseph Akhigbe \\ Oyam-Jajaboma Gail
}

Department Of Management, Faculty Of Management Sciences, University Of Port Harcourt, Rivers State, Nigeria

doi: 10.19044/esj.2017.v13n22p125 URL:http://dx.doi.org/10.19044/esj.2017.v13n22p125

\begin{abstract}
Job burnout and organizational cynicism are two intertwined phenomena which have adverse effects on organizations. The main purpose of this study is to examine the relationship between job burnout and organizational cynicism of employees in Nigerian Banks. The study adopted the cross-sectional survey method which is a form of the quasi-experimental research design. The study had a sample size of 214 employees drawn out from an accessible population of 499 bank employees in Port Harcourt using the Krejcie\& Morgan (1970) table. The study research instruments were distributed to the accessible population using the Bowley's (1964) population allocation formula of proportion. The Spearman rank correlation coefficient was used in testing the study hypotheses. The study findings reveal that there is a significant relationship between the two dimensions of job burnout used in this study and organizational cynicism. The study recommended among others that banks should give their employees breaks and time off from time to time in order to guide against emotional exhaustion since it has a significant relationship with organizational cynicism, this would give employees the opportunity to balance their work-life and family life. Conclusively, the study has extensively looked at the relationship between job burnout and organizational cynicism.
\end{abstract}

Keywords: Organizational cynicism, job burnout, emotional exhaustion, inefficacy, burnout syndrome, cynicism

\section{Introduction}

The Nigerian banking sector, like every other organization in Nigeria, is facing cynicism problem which is almost like a social problem today. Organizational cynicism is employees having negative feelings and emotions towards the organization, managers, co-workers and clients/customers. When 
a worker believes that his/her efforts are not relevant to solve the different problems of the organization, such an employee can result to cynicism (McClough, Rogelberg, Fisher, \& Bachiochi, 1998). There is a spectrum of negative effects, emotions and feelings of organizational cynicism like jealousy, fear, sadness, disappointment, embarrassing feeling about the organization, hopelessness, dishonour, irritation, depression, anger, shame, boredom, contempt, lost, exhaustion, fatigue, despair, disturbance, dissatisfaction and hopelessness about the staff and organization, detachment, enslavement, alienation, disbelief of others, misery, doubt, disdain, discouragement, and underestimation; and cynicism is relates with reduction in organizational performance, conflicts among workers, staff circulation acceleration, brain drain, absenteeism, abasement, scorn, resignation, suspicion, withdrawal behaviour, contempt, disillusionment, job turnover, and burnout (Clarke, 1999; Dean, Brandes\&Dharwadkar, 1998; Naus, Van Iterson, \& Roe, 2007; Ozgener, Ogut\& Kaplan, 2008; Ozler, Atalay\&Sahin, 2010; Ozler\&Atalay, 2011; Abraham, 2000; Shahzad\&Mahmood, 2012; Andersson, 1996; and Andersson\& Bateman, 1997).

Burnout Syndromes include such factors as mental, emotional and physical fatigue, disappointment, exhaustion, loss of energy, failure, unfulfilled wishes, cynicism, ineffectiveness, working conditions, and family experience (Freudenberger, 1974; Dimitrios\&Konstantinos, 2014). Burnout reactions represent people who withdraw, alienate themselves, and appear depressed as they go through the dynamics of their job and simply survive to qualify for a pension (Stohr, Lovrich, \& Wilson, 1994). In addition, Schaufeli, \& Bakker (2004) refer to job burnout as the connection between job demands and job resources. Employees experience job burnout in their daily communications with co-workers and customers and can be associated to both individual and organizational factors (Dimitrios\&Konstantinos, 2014). Employees react to burnout syndromes in their workplaces by developing a cynical temperament towards the organization. In modern times, employees in banks are especially among the workgroups affected by burnout syndrome. The intense work load and long hours required by banking organizations leads to organizational cynicism which has negative effects on the organization (Ozgener, Ogut, \& Kaplan, 2008). Job burnout of personnel will reduce effectiveness and efficiency of the organization; in this event, the organization will not attain its goals and aspirations (Love, Peter, Goh, Hogg, Robson, \& Irani, 2011).

Most research studies have linked burnout with several negative variables, but very few researches have been carried out on the specific relation between job burnout and organizational cynicism. Over the years, researchers have become curious about the subjects relating to organizational 
cynicism. Chiaburu, Peng, Oh, Banks, \&Lomeli (2013) reveals that organizational cynicism is associated with diverse inexpedient outcomes such as abridged organizational commitment, heightened employee turnover intentions and declining performance. These negative payoffs are also ramifications of job burnout, which convey that a connection exists between job burnout and organizational cynicism, and it is also conceivable that organizational cynicism is the mediating variable in the correlation between burnout and other variables. This therefore makes it imperative to study the link between job burnout and organizational cynicism which very few studies have been done. The study seeks to critically examine the two dimensions of job burnout - emotional exhaustion and inefficacy and organizational cynicism. This is a vital gap that needs to be explored because this is an issue that cuts across most organizations affecting performance, rate of turnover, commitment and job satisfaction. Also it is crucial to fully understand the ramifications of job burnout and organizational cynicism as a result of conspicuous problem that many organizations are facing today.

\section{Statement of Problem}

Simha, Elloy, \& Huang (2014) assert that if individuals get burned out from their jobs, they are likely to harbour negative attitudes toward their organizations, and also display behaviours that are disparaging to others giving rise to the problem of organizational cynicism which is detrimental to the organization. Individuals in the banking sector who are cynical can influence their entire banking organizations and can prevent the organization from achieving its set goals (Nafei, 2013). Bank employees exhibit cynical behaviours which affects the way service is delivered in the banks due to burn out from the demands of the job. In modern times, things have changed due to globalization, technological factors, and diversity in the work place, thus banking organizations are faced with the enormous challenges of maintaining high service standards (Khan, 2014). Job burnout has been associated with adverse health issues such as anxiety, depression, reduced self-worth and headaches (Cordes\& Dougherty, 1993). With all these, the employees end up not being happy at the job and hence become cynical, less committed to the job and plan to leave the job. All these are unfavourable to the growth and performance of the organization. When the demands in the banks are on the increase, employees of such banks develop cynical attitudes towards their bank to deal with the problem of being burned out. In today's world, advancements and changes compel organizations and their employees to change. Contrary to this, if the organizations are only concerned with the proficiency of the organization involving usage and fail to take the attitudes and emotions of their employees into consideration, the employees will take note of this trend and will become disconcerted thereby developing negative 
sentiments towards their organization. All these circumstances cause the birth of deliberations and researches conducted on job burnout and organizational cynicism (Yetim \& Ceylan, 2011).

\section{The Study Operational Framework}

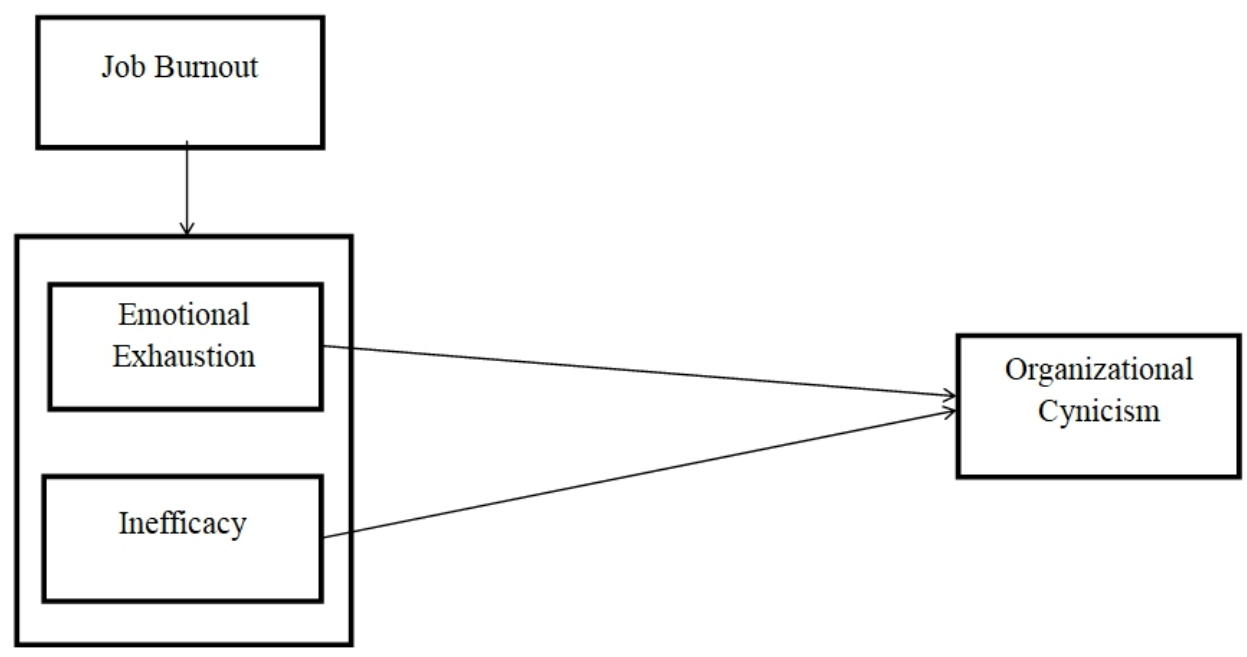

Figure 1: Conceptualized by the researcher from Ozler\&Atalay, 2011.

The above model (operational framework) shows the relationship between the dependent and independent variables. The criterion variable is "organizational cynicism" while the predictor variable is "job burnout" and its dimensions are emotional exhaustion and inefficacy (Akca, 2008; Kacmaz, 2005; Kayabasi,2008; Maslach\&Leiter, 2005; Maslach\& Goldberg, 1998; Maslach\& Jackon,1981; and Polat, et al, 2009).

\section{Objectives of the Study}

The general purpose of this study is to examine the relationship between Job Burnout and Organizational Cynicism. The specific objectives of this study are as follows:

1. To examine the relationship between emotional exhaustion and organizational cynicism of bank employees in Port Harcourt.

2. To determine the relationship between inefficacy and organizational cynicism of bank employees in Port Harcourt.

\section{Research Questions}

To accomplish the objectives of this study, we are asking the following questions:

1. What is the relationship between emotional exhaustion and organizational cynicism of bank employees in Port Harcourt? 
2. What is the relationship between inefficacy and organizational cynicism of bank employees in Port Harcourt?

\section{Research Hypotheses} study:

The following hypotheses are formulated for the purpose of this Ho1 There is no significant relationship between emotional exhaustion and organizational cynicism of bank employees in Port Harcourt.

$\mathrm{Ho}_{2}$ There is no significant relationship between inefficacy and organizational cynicism of bank employees in Port Harcourt..

\section{Literature Review}

\section{The Concept of Organizational Cynicism}

Cynics believed 'virtue' to be the only 'good' of human existence and the only means of achieving such virtue was through 'self-control', often achieved through 'pointing out the flaws in others' as flaws to be avoided in oneself. Through similar behaviours, the cynics of modern time have become known as "faultfinders." A modern cynic, according to Merriam-Webster Dictionary (2003) is: "A person who believes all people are motivated by selfishness, and whose outlook is scornfully and often habitually negative". Cynicism is enigmatic in that the cynic must hold both affirmative feelings (amenable of the organization) and contradictory feelings (impending lack of success of change efforts) synchronously (McColough, Rogelberg, Fisher, \&Bachiochi, 1998). Over generations the terms "cynic", "cynical", and "cynicism" have occupied a place in our language, with meanings that are approximately derived from the precepts of Cynicism (Dean, Brandes, \&Dharwadkar, 1998). In recent times, acknowledgement and understanding present-day cynicism contradicts its antiquated meanings and concepts. Since the1990s, cynicism is esteemed in such areas as psychology, sociology, and management. The meanings and concept of cynicism have unfolded through different studies (Quian, 2007).

Cynicism can be seen as a person being negative and pessimistic about others. Employees who are cynical can influence the whole organization and hamstring the organization from arriving at its goals. Employees who are cynical have the belief that their confederates are selfish and self-centred (Barefoot, Dodge, Peterson, Dahlstrom, \& Williams, 1989). According to Dean, Brandes, \&Dharwadkar (1998), organizational cynicism is seen as one expressing a negative demeanour towards the organization they work for and it incorporates three measures: (1) a belief that the organization has no integrity; (2) negative affect toward the organization; and (3) tendencies of derogative and detracting behaviours toward the organization that are uniform with these beliefs and affect. Some factors that 
influence cynicism are handling stress, feud with organizational anticipations, inadequate social foundation and acknowledgement, not having a voice in the decision-making process, disproportionate distribution of power, and inadequate communication (Reichers, Wanous, \& Austin, 1997). Andersson (1996) defines organizational cynicism as general or specific attitudes of disappointment, insecurity, hopelessness, anger, mistrust of institutions or individuals, groups, ideology, and social skills. Organizational cynicism is the belief that an organization is not honest which causes hard-hitting reputation and critical behaviours when it is combined with a strong negative emotional response (Abraham, 2000). To add up, cynicism has become the norm in many organizations in Nigeria and other countries around the world. Some may contend that this is as a direct result of job contentment levels declining over the last decade (Koretz, 2003). Abraham (2000) posits that the reason for employees' having negative decorum against their organization is a kind of tactics for tackling with their conditions that were not met.

According to Dean, Brandes, \&Dharwadkar (1998), the first measure of cynicism is Cognitive cynicism (belief), the second measure is Affective cynicism (affect), and the final measure is Behavioural cynicism (behaviour). The first measure which is cognitive cynicism is the employees' belief that the organizations they work for is not being honest with them, are unfair in their practices, and are not straightforward with them. Employees may therefore associate themselves with dissenting attitudes such as deception, fabrication, conspiracy, and manipulation. The employees believe that their organizations are self-centred and on this account they abandon their good morals involving themselves in dissipated and treacherous attitudes (Brandes, 1997; Brandes\& Das, 2006; and Dean, Brandes, \&Dharwadkar, 1998). According to Dean, Brandes, \&Dharwadkar (1998) affective cynicism involves several emotions such as contemptuous feelings, feelings of animosity directed at the organization, distress, disgust, and feelings of shame when they have thoughts of their organization. The final measure of organizational cynicism which is Behavioural cynicism has to do with nugatory tendencies and derogatory behaviour (Dean, Brandes, \&Dharwadkar, 1998).

\section{The Concept of Job Burnout}

Research on burnout had its origin in care-giving and service professions, in which the crux of the job was the relationship between provider and receiver. This interpersonal context of the job meant that, from the infancy, burnout was studied not just as an individual stress reaction, but in terms of an individual's relational transactions in the workplace (Maslach, Schaufeli, \&Leiter, 2001). Moreover, this interpersonal context focused 
concentration on the individual's emotions, and on the intention and values underlying his or her work with the receivers. The clinical and social psychological perspectives of the initial articles influenced the nature of the first phase of burnout research. On the clinical side, the focal point was on symptoms of burnout and on issues of mental health. On the social side, the focal point was on the relationship between the provider and receiver and on the situational context of service occupations (Maslach, Schaufeli, \&Leiter, 2001).

Burnout therefore can be defined as employees' having the feelings that their physical and psychological resources have been worn out based on the constant attempt toward a work-related objective and is often the results of too much work pressure and stress, most especially if the pressure is as a result of insurmountable work goals (Gerber,Nel, \& Van Dyk, 1999). Maslach\& Pines (1977) posits that in the case of burnout, the employee detaches him/herself from customers and the job, therefore changing his/her attitude from being considerate to insensitivity. Job Burnout takes place when the organizational conditions are beyond bearing and prejudiced, to the extent that not even personal factors are adequate to withstand their effects (Bosman, Buitendach, \&Laba, 2005).

After the first introduction of burnout syndrome, so many definitions were given, yet the most accepted definition was the one made by Maslach. He characterized the syndrome of job burnout by three dimensions which include; Emotional exhaustion- abatement of emotional resources to get in touch with other people; Depersonalization- having negative emotional and cynical attitudes towards one's service or the receiver of attention; and Inefficacy- inclination to evaluate one's self negatively particularly in respect to the job (Polikandrioti, 2009). According to Maslach, emotional exhaustion accounts for depersonalization and depersonalization accounts for Inefficacy (Ozler\&Atalay, 2011). Also, Maslach (2003) anticipates that these three dimensions can vary depending on variant working conditions. For example, any work or working condition may rest on very hard job relations with colleagues and it leads to emotional exhaustion, hitherto it can also present new opportunities for the success. In addition working conditions may be difficult and tiresome and can lead to depersonalization; furthermore, with no clear objectives this condition may cause Inefficacy (SağlamAri\&Bal-Çına, 2008).

Emotional exhaustion is the take-off, inmost and the most important dimension of job burnout (Ozler\&Atalay, 2011). This dimension is associated mostly to job stress. The employee working emotionally under a swamped workload forces one's self and is put upon by other people's emotional demands. Emotional exhaustion becomes apparent as a reaction to this situation (Ungüren, Doğan, Özmen, \&Tekin, 2010). Depersonalization 
on the other hand involves being pessimistic, being insensible or undue indifference in relating with others. Depersonalization is generally a response to the extreme strain resulting from emotional exhaustion and focuses on preserving itself at first sight. This indifference has the risk of turning into depersonalization. Depersonalization is the component of burnout which represents the interpersonal dimension (Maslach\& Goldberg, 1998). And finally, Inefficacy refers to a decline in efficacy and productivity felt in the job. The feeling of self-efficacy is linked negatively to depression and feebleness in dealing with job requirements. These feelings upsurge with the dearth of social support and professional development opportunities at work. Inefficacy is a component of burnout which represents the self-evaluation dimension (Maslach\& Goldberg, 1998).

\section{Methodology}

The study adopted a quasi-experimental research design. The crosssectional survey method which is a form of the quasi-experimental design was considered most appropriate for this study. The cross-sectional survey can be thought of as analogous to the taking of a snapshot of some situation and analysing it. The survey relies on a sample of elements from the population of interests which are measured at a single point in time (Baridam, 2008). The population was large and diverse, thus the appropriateness of the cross-sectional survey, widely used in the administrative and social sciences, taking cognizance of the complex relationships that exist between the study variables. Employees of the banks and their branches in Nigeria represent the target population. The accessible population for this study were the employees of a branch of the commercial banks in Port Harcourt, Rivers State which consists of 499 employees of the nineteen (19) commercial banks out of the twenty-two (22)commercial banks in Nigeria and the sample of the study were selected thereon which were a representative of the accessible population.

The population of this study were employees from the Operations unit, Business unit and Administrative unit of the nineteen (19) Commercial Banks in Port Harcourt, Rivers State out of the twenty-two (22) commercial banks in Nigeria.The choice of respondents from each bank was determined through the simple random sampling technique. Here each sampling unit had an equal chance of being selected as the first member of the sample and after the first member was selected, each of the remaining units in the population had an equal chance of being the second member of the sample. The Sample size was determined using the Krejcie\& Morgan (1970) table. Where on the table, a population $(\mathrm{N})$ of 499 gives a sample size $(\mathrm{S})$ of 214 . Hence the sample for this study was 214 based on a population size of 499. Primary data and secondary data were utilized in this study. The questionnaire was 
the main instrument for collecting primary data for this study. The questionnaires was personally administered through the use of resource persons to the randomly chosen employees of the nineteen (19) Commercial Banks in Port Harcourt, Rivers State out of the twenty-two banks in Nigeria being studied. Also, since our data was collected in ordinal form, Spearman Rank Order Correlation Coefficient was used for the data analysis. This was made possible by the application of the Statistical Package for Social Sciences (SPSS).

\section{Results}

The study being predominantly quantitative, generated data using the structured questionnaire; a total of 214 copies of the questionnaire were distributed to target banks within a specified time-frame; copies were manually distributed through established contacts in the selected banks, thereafter retrieval was also accomplished through same contacts in the banks. Retrieval of distributed copies recorded a success of 154 copies, thus accounting for $72 \%$ of the total number intended for the study; thereafter, copies were examined and cleaned for errors, missing values and blank sections.

\section{Hypothesis One}

Spearman's Correlation of Emotional Exhaustion and Organizational Cynicism

\begin{tabular}{|c|c|c|c|c|}
\hline \multicolumn{5}{|c|}{ Correlations } \\
\hline & & & $\begin{array}{c}\text { Emotional } \\
\text { Exhaustion }\end{array}$ & $\begin{array}{c}\text { Organizational } \\
\text { Cynicism }\end{array}$ \\
\hline \multirow{7}{*}{ Spearman's rho } & \multirow{4}{*}{$\begin{array}{l}\text { Emotional } \\
\text { Exhaustion }\end{array}$} & Correlation Coefficient & 1.000 & .446 \\
\hline & & & & \\
\hline & & Sig.(2-tailed) & - & .000 \\
\hline & & $\mathrm{N}$ & 154 & 154 \\
\hline & \multirow{3}{*}{$\begin{array}{l}\text { Organizational } \\
\text { Cynicism }\end{array}$} & Correlation Coefficient & .446 & 1.000 \\
\hline & & Sig.(2-tailed) & .000 & . \\
\hline & & $\mathrm{N}$ & 154 & 154 \\
\hline
\end{tabular}

Source: Data Output, (2017).

The data reveals a significant relationship between emotional exhaustion, which is a dimension of job burnout and organizational cynicism. The result is interpreted as follows:

Emotional Exhaustion and organizational cynicism: The results of the analysis reveal that there is a significant relationship between emotional exhaustion and organizational cynicism. This is as the rho value $=.446$ and level of significance where $\mathrm{P}=.000$ indicate a substantial level of 
association between both variables; hence based on the decision rule of $\mathrm{P}<$ 0.05 for the tests, the null hypothesis is hereby rejected as the result shows a significant relationship between emotional exhaustion and cognitive cynicism.

\section{Hypothesis Two}

Spearman's correlation of Inefficacy and organizational cynicism

\begin{tabular}{|c|c|c|c|c|}
\hline & & & Inefficacy & $\begin{array}{c}\text { Organizational } \\
\text { Cynicism }\end{array}$ \\
\hline \multirow{7}{*}{ Spearman's rho } & \multirow{3}{*}{ Inefficacy } & Correlation Coefficient & 1.000 & .553 \\
\hline & & Sig.(2-tailed) & • & .000 \\
\hline & & $\mathrm{N}$ & 154 & 154 \\
\hline & \multirow{4}{*}{$\begin{array}{l}\text { Organizational } \\
\text { Cynicism }\end{array}$} & Correlation Coefficient & .553 & 1.000 \\
\hline & & Correlation Coefficient & & \\
\hline & & Sig.(2-tailed) & .000 & . \\
\hline & & $\mathrm{N}$ & 154 & 154 \\
\hline
\end{tabular}

Source: Data Output, (2017).

The data reveals a significant relationship between inefficacy, which is a dimension of job burnout and organizational cynicism. The result is interpreted as follows:

Inefficacy and Organizational cynicism: The results of the analysis reveal that there is a significant relationship between Inefficacy and organizational cynicism. This is as the rho value $=.553$ and level of significance where $\mathrm{P}=.000$ indicate a high level of association between both variables; hence based on the decision rule of $\mathrm{P}<0.05$ for the tests, the null hypothesis is hereby rejected as the result shows a significant relationship between Inefficacy and organizational cynicism.

\section{Summary of the Hypotheses Testing Results}

\begin{tabular}{|c|c|c|}
\hline Hypotheses & Significance & Final Result \\
\hline $\begin{array}{c}\mathrm{Ho}_{1} \text { : there is no significant relationship } \\
\text { between emotional exhaustion and } \\
\text { organizational cynicism of bank employees in } \\
\text { Port Harcourt. }\end{array}$ & Significant & Rejected \\
\hline $\begin{array}{c}\mathrm{Ho}_{2} \text { : there is no significant relationship } \\
\text { between Inefficacy and organizational } \\
\text { cynicism of bank employees in Port Harcourt. }\end{array}$ & Significant & Rejected \\
\hline
\end{tabular}




\section{Discussion of Findings}

This study examined the correlation between job burnout and organizational cynicism of bank employee's in Port Harcourt.

\section{Emotional Exhaustion and Organizational Cynicism}

The result of the analysis reveals that emotional exhaustion is significantly associated with organizational cynicism; this implies that emotional exhaustion is considerably important in boosting organizational cynicism and expressions towards work in the organization. This argument shares a similar view with Leiter\&Maslach (2004), who posit that it involves the feelings of being overextended and drained of one's emotional and physical resources. The employee therefore reacts in an emotional or sentimental way towards the organization (Nafei, 2013).Facetiously, the cynical employees feel a shrouded enjoyment of their superiority to the organization. Also in Polat, et al (2009), he posits that when the employee is emotionally consumed (excessively), it emerges as reaction to this lack of energy and the feeling of losing emotional sources. The individual feels that his/her emotional sources has been exhausted, experiences an emotional fatigue and thinks that he/she does not act to the people he/she provides service as reasonable as before. It is too hard to go to work another day for a staff who cannot overcome the feeling of tension and anxiety. Thereby, an inefficient situation emerges both for the staff and institution, such as being late to work, absenteeism as a result of psychosomatic complaints, job leavings etc (Kayabasi, 2008).

\section{Inefficacy and Organizational Cynicism}

The analysis reveals that there is a significant relationship between inefficacy and organizational cynicism; this implies that employees' tend to decrease in efficacy and productivity felt in the job. The feeling of selfefficacy is negatively related to depression and incapability of coping with job requirements. These feelings increase with the insufficiency of social support and professional development opportunities at work (Maslach\& Goldberg, 1998). It describes the individual's tendency to evaluate him/herself negatively. An individual experiencing a decrease in personal development feels insufficient, thinks that he is not complete and experiences a decrease in motivation and also a negative viewpoint about himself/herself and thinks that he has not moved forward in his job, has even moved backward, his efforts are in vain and cannot create a difference around himself (Saglam-Ari \&Cina-Bal, 2008). 


\section{Conclusion}

In conclusion the study has extensively looked at the relationship between job burnout and organizational cynicism.

Emotional exhaustion as an attribute and dimension of job burnout is an exhaustion of an individual's emotions and feelings toward other people. Emotional exhaustion asserts that individuals showing cynical attitudes have some certain beliefs. Organizations lack a solid understanding of organizational principles and official rules are ignored by employees. Relations are carried out depending on the individual interest.

Inefficacy as a dimension of job burnout refers to employees feeling a sense of loss in their capabilities and productiveness. Employees experience a sense of loss when evaluating themselves and this has an impact on the organization. And these dimensions have a significant relationship with cognitive cynicism, affective cynicism, and behavioural cynicism.

\section{Recommendation}

As a result of the findings and conclusion of the study, the following recommendations are herein proffered:

i.Banks should give their employees breaks and time off from time to time in order to guide against emotional exhaustion since it has a significant relationship with organizational cynicism, this would give employees the opportunity to balance their work-life and family life.

ii.Banks need to conduct seminars and trainings on social support and professional development opportunities at workfrom time to time to increase their employees' level of development and productivity felt in the job in order to guide against inefficacysince it has a significant relationship with organizational cynicism.

\section{Contribution to Knowledge}

This study has succeeded in examining the relationship between job burnout and organizational cynicism of bank employees in Port Harcourt and thus has contributed to the existing literature in the area of emotional exhaustion, inefficacy, organizational cynicism and organizational culture.

The study further contributed to knowledge by expounding on the need for banks to become aware of this prevalent issue of job burnout and organizational cynicism which has been neglected and which in the long run affects both the performance of the employees and the banks. The study revealed the need for banks to develop their policies and practices to include the wellbeing of their employees. 


\section{References:}

1. Abraham, R. (2000). Organizational cynicism: Bases and consequences: Generic, social and general. Psychology Monographs, 126(3), 269-292.

2. Akça, F. (2008).Örgütseltükenmişlikvestres, içindeözdevecioğlu, M. VeKaradal, H., (Ed.), Örgütseldavranıştaseçmekonular:organizasyonlarınkaranlıkyönlerive verimlilikazaltıcıdavranışlar, Ankara: İlkeYayınevi, 107-123.

3. Andersson, L. (1996). Employee cynicism: An examination using a contract violation framework. Human Relations, 49(11), 1395-1418.

4. Andersson, L., \& Bateman, T. S. (1997). Cynicism in the workplace: Some causes and effects. Journal of Organizational Behaviour, 18(5), 449-469.

5. Barefoot, J., Dodge, K., Peterson, B., Dahlstrom, W., \& Williams, R. (1989). The cook-medley hostility scale: Item content and ability to predict survival. Psychosomatic Medicine, 51, 46-57.

6. Baridam, D. M. (2008).Research method in administrative sciences ( $3^{\text {rd }}$ ed.). Port Harcourt: Sherbrook Associate.

7. Bosman, J., Buitendach, J. H., \&Laba, K. (2005).Job insecurity, burnout and organizational commitment among employees of a financial institution in Gauteng.SA Journal of Industrial Psychology, 31(4), 32-40.

8. Brandes, P. M. (1997). Organizational cynicism: Its nature, antecedents, and consequences, Unpublished Ph.D. Dissertation, Division of research and advanced studies of the University of Cincinnati, USA.

9. Brandes, P., \& Das, D. (2006). Locating behavioural cynicism at work: Construct issues and performance implications, employee health, coping and methodologies, In L. Pamela Perrewe, C. Daniel Ganster (Eds.), New York, JAI Press, 233-266.

10. Chiaburu, D. S., Peng, A. C., Oh, I. S., Banks, G. C., \&Lomeli, L. C. (2013). Antecedents and consequences of employee organizational cynicism: A meta-analysis. Journal of Vocational Behavior, 83(2), 181-197.

11. Clarke, M. (1999). Management development: A new role in social change?.Management Decision, 37(10), 767-777.

12. Cordes, C. L., \& Dougherty, T. W. (1993).A review and an integration of research on job burnout. Academy of Management Review, 18(4), 621-656.

13. Dean, J. W., Brandes, P., \& Dharwadkar, R. (1998).Organizational cynicism. Academy of Management Review, 23(2), 341-352.

14. Dimitrios, B., \&Konstantinos, V. (2014). Organizational culture and 
job burnout: A review. International Journal of Research in Business Management, 2(1), 43-62.

15. Freudenberger, H. J. (1974). Staff burnout. Journal of Social Issues, $30,159-165$.

16. Gerber, P. D., Nel, P. S., \& Van Dyk, P. S. (1999).Human resource management $\left(4^{\text {th }}\right.$ ed.). New York: Oxford.

17. Kaçmaz, N. (2005). Tükenmişlik (Burnout) sendromu.İstanbul Tip FakültesiDergisi, 68, 29-32.

18. Kayabaş1,

Y.

(2008).

Bazıdeğişkenleraçısındanoğretmenlerinmeslekitükenmişlikdüzeyleri. SosyalBilimlerDergisi, 20, 191-212.

19. Khan, M. A. (2014). Organizational cynicism and employee turnover intention: Evidence from banking sector in Pakistan. Pakistan Journal of Commerce and Social Sciences, 8(1), 30-41.

20. Koretz, G. (2003). Hate your job? Join the club. Business Week.

21. Krejcie, R. V. \& Morgan, D. W. (1970). Determining sample size for research activities.Educational and Psychological Measurement, Journal of Social Issues 30, 607-610.

22. Leiter, M. P., \& Maslach, C. (2004). Areas ofworklife: A structured approach to organizational predictors of job burnout. Emotional and Physiological Processes and Positive Intervention Strategies Research in Occupational Stress and Well Being, 3, 91-134.

23. Love, P. E. D., Goh, Y. M., Hogg, K., Robson, S., \&Irani, Z. (2011).Burnout and sense of coherence among residential real estate brokers.Safety Science, 49, 1297-1308.

24. Maslach, C., \& Jackson, S. E. (1981). The measurement of experienced burnout.Journal of Occupational Behaviour, 2(2), 99113.

25. Maslach, C. (2003). Job burnout: New directions in research and intervention. Current Directions in Psychological Science, 12(5), 189-192.

26. Maslach C. \& Goldberg J. (1998). Prevention of burnout: New perspectives. Applied \& Preventive Psychology, 7, 63-74.

27. Maslach, C., \&Leiter, M. P. (2005). Stress and burnout: The critical research, In Copper, C. L. (Ed.), Handbook of stress medicine and health, Lancaster, CRC Press, 155-172.

28. Maslach, C. \& Pines, A. (1977).The burnout syndrome in the day care setting.Child Care Quarterly, 6, 100-113

29. Maslach, C., Schaufeli, W. B., \&Leiter, M. P. (2001).Job burnout. Annual Review Psychology, 52, 397-422.

30. McClough, A. C., Rogelberg, S. G., Fisher, G. G., \&Bachiochi, P. D. (1998). Cynicism and the quality of an individual's contribution to an 
organizational diagnostic survey.Organization Development Journal, $16,31-42$.

31. Merriam-Webster, Inc. (2003). Webster's Tenth New Collegiate Dictionary. Springield, MA: Author.

32. Nafei, W. A. (2013). The effects of organizational cynicism on job attitudes: An empirical study of teaching hospitals in Egypt. International Business Research, 6(7), 52-69.

33. Naus, F., Van Iterson, A. \& Roe, R. A. (2007). Organizational cynicism: Extending the exit, voice, loyalty, and neglect model of employees' responses to adverse conditions in the workplace, Human Relations, 60 (5), 683-718.

34. Özgener, Ş., Öğüt, A., \& Kaplan, M. (2008). A new paradigm in employee-employer relations: Organisational cynicism. In $\mathrm{M}$. Ozdevecioglu\& H. Karadal (Eds.), Selected subjects in organizational behaviour, Ankara: IIke Publishing House.

35. Ozler, D. E., \&Atalay, C. G. (2011). A research to determine the relationship between organizational cynicism and burnout levels of employees in the health sector. Business and Management Review, 1(4), 26-38.

36. Özler, D. E., Atalay, C. G., \&Şahin, D. (2010).ÖrgütlerdeSinizmGüvensizlikleMiBulaşır

37. OrganizasyonveYönetimBilimleriDergisi, 2(2), 47-57.

38. Polat, G., Topuzoğlu, A., Gürbüz, K., Hotalak, Ö.,Kavak, H., Emirikçi, S., \&Kayış, L. (2009). Bilecikili, bozüyükilçesi, liseoğretmenlerindetükenmişliksendromu. TAF Preventive Medicine Bulletin, 8(3), 217-222.

39. Polikandrioti, M. (2009).Burnout syndrome.Health Science Journal, 3(4), 195-196.

40. Quian, Y. (2007). A communication model of employee cynicism toward organizational change. A dissertation presented to the faculty of the Scripps College of Communication of Ohio University in partial fulfilment of the requirements for the degree of Doctor of Philosophy.

41. Reichers, A., Wanous, J., \& Austin, J. (1997).Understanding and managing cynicism about organizational change. Academy of Management Executive, 11(1), 48-59.

42. Saglam-Ari, G. \&Cina-Bal, E. (2008). The concept of burnout: Its importance for individuals and organizations. Management and Economy, 15(1), 131-148.

43. Schaufeli, W. B., \& Bakker, A. B. (2004). Job demands, job resources, and their relationship with burnout and engagement: A multi-sample study. Journal of Organizational Behaviour, 25, 293- 
315.

44. Shahzad, A., \&Mahmood, Z. (2012). The mediating-moderating model of organizational cynicism and workplace deviant behaviour: Evidence from banking sector in pakistan. Middle-East Journal of Scientific Research, 12(5), 580-588.

45. Simha, A., Elloy, D. F., \& Huang, H. (2014). The moderated relationship between job burnout and organizational cynicism.Management Decision, 52(3), 482-504.

46. Stohr, M. K., Lovrich, N. P., \& Wilson, G. L. (1994). Staff stress in contemprorary jails: Assessing problem severity and the payoffs of progressive personnel practices. Journal of Criminal Justice, 22(4), 313-327.

47. Üngüren E., Doğan H., Özmen M., \&Tekin Ö. A. (2010).OtelçalışanlarınıntükenmişlikveişTatminilişkisi.Journal of Yaşar University, 17(5), 2922-2937.

48. Yetim, S. \&Ceylan, A., Ö. Ö. (2011).Örgütselsinizmveörgütselvatandaşlıkarasındakiilişkileribelirle meyeilişkinbiraraştirma. E- Journal of New Sciences Academy (NWSA), 6(1), 682-695. Retrieved from http://www.newwsa.com/sayi_detay.asp?d=2\&dergi_id=1\&sayi_id=165 